\title{
Environmental Impact on Duration of Flowering and Fruiting of Rattan (Calamus castaneus) in Peninsular Malaysia
}

\author{
Nur Diana Mohd Rusdi' ${ }^{1}$, Asyraf Mansor ${ }^{1,2 *}$, Shahrul Anuar Mohd Sah ${ }^{1,2}$, Rahmad \\ Zakaria $^{1}$ and Nik Fadzly Nik Rosely ${ }^{1}$
}

${ }^{1}$ School of Biological Sciences, Universiti Sains Malaysia, 11800, Pulau Pinang, Malaysia

${ }^{2}$ Centre for Marine and Coastal Studies (CEMACS), Universiti Sains Malaysia, 11800, Pulau Pinang, Malaysia

\begin{abstract}
The phenological events of rattan were seldomly studied due to its nature of survival by climbing on other trees (i.e., liana). However, some rattans are non-climbing and found to produce fruits throughout the year. Therefore, it aimed to record Calamus castaneus duration of flowering and fruiting over a year and identify which environmental variables affect the duration. This study was conducted for 12 months in three forest reserves, namely Bukit Mertajam Forest Eco-Park (BMFEP), Teluk Bahang Forest Reserve (TBFR), and Segari Melintang Forest Reserve (SMFR). Five study plots (10 m x $10 \mathrm{~m}$ each) were established, and overall, 53 C. castaneus individual palm in the plots were monitored. Findings have revealed that female inflorescences bloomed shorter than males. Also, C. castaneus fruits take about three to four months to get matured. The canonical correspondence analysis (CCA) highly regulated the event by microclimate and locality. Thus, the flowering and fruiting duration may not directly be affected by a very specific environmental factor.
\end{abstract}

Keywords: Calamus castaneus, duration, environment, flowering, fruiting, rattan

ARTICLE INFO

\section{Article history:}

Received: 23 July 2021

Accepted: 24 November 2021

Published: 24 January 2022

DOI: https://doi.org/10.47836/pjtas.45.1.08

\section{E-mail addresses:}

diana_ladyv93@yahoo.com (Nur Diana Mohd Rusdi)

asyrafm@usm.my (Asyraf Mansor)

sanuar@usm.my (Shahrul Anuar Mohd Sah)

rahmadz@usm.my (Rahmad Zakaria)

nfadzly@usm.my (Nik Fadzly Nik Rosely)

*Corresponding author

ISSN: 1511-3701

e-ISSN: 2231-8542

\section{INTRODUCTION}

Calamus was among the 13 genera of rattan with the highest economic value. This genera comprises 370 species, recorded international rattan trade with over USD 6.5 billion a year (Ali \& Barizan, 2001; Dransfield, 1979; Wan Ariffin et al., 2018). Rattan, in general, is a spiny, climbing palm that uses its climbing organ (flagella or cirrus) to hook other trees to reach for 
sunlight (Dransfield, 2001). Thus, the interaction with its immediate surrounding is interesting and crucial both biologically and ecologically. Working in a natural forest is extremely tough and time-consuming. Therefore, we decided to study Calamus castaneus (Figure 1), an acaulescent, dioecious rattan, to avoid difficulty in observing its reproductive biology. Unlike other rattan species, this species does not possess a climbing organ, and it also produces flowers and fruit throughout the year. Calamus castaneus was chosen as a study subject due to the low exploitation of its cane, therefore making its natural population unaffected (Kidyoo \& McKey, 2012). The flowering and fruiting events continue throughout the year, making this species an important food source for wildlife within its surrounding.

Despite low commercial value as cane, this species provides flowers and fruit for animals and insects as a reward for pollination and seed dispersals (Watanabe \& Suzuki, 2008). The flower's crimson red colour would attract insects, helping pollination between male and female plants. Among the admirer of these sweet yet acidic fruits are primates such as macaques (Ruppert et al., 2016). In addition, the leaf sheath makes an excellent roofing material, and the immature fruit was consumed by aboriginal people to cure cough (Dransfield, 1979).

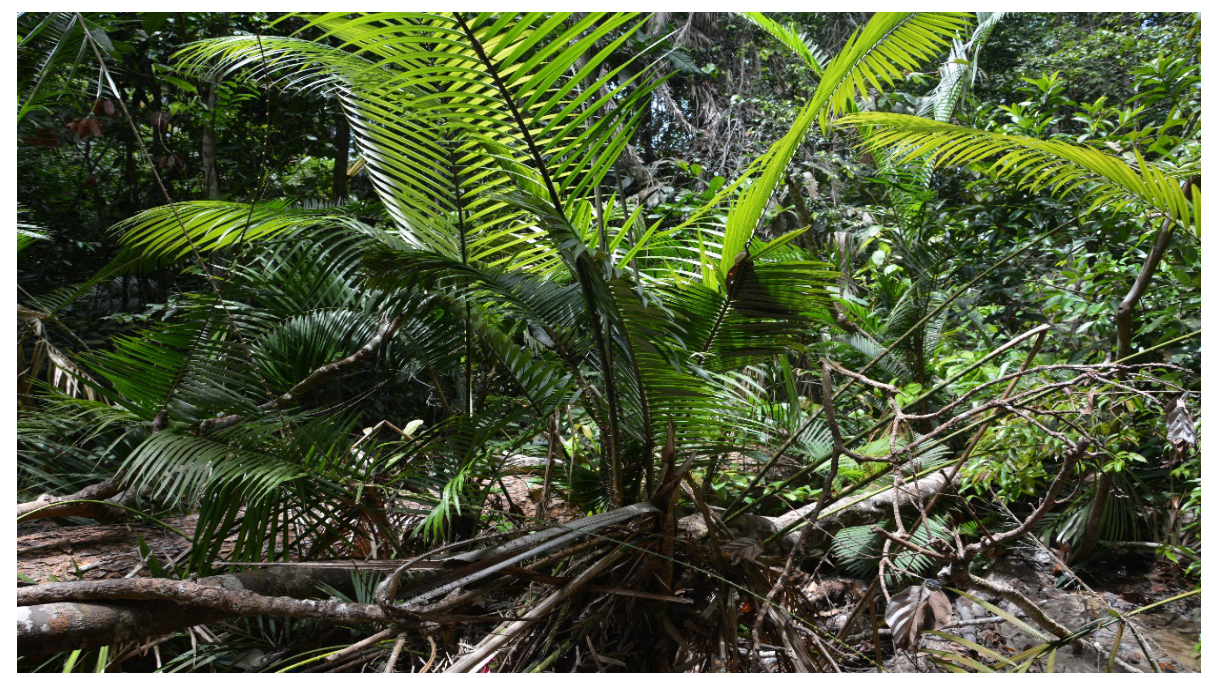

Figure 1. Calamus castaneus Griff. is an acaulescent, dioecious rattan

In terms of ecology, this species plays a home for the ants. In return, the ants supply major role in symbiosis with ants (Dransfield, 1979). Based on observation, the broad, lush leaf sheath holds the fallen dry leaves from the canopy into the crown, hence creating a nutrients for the host and nourish the soil around them. This process was crucial to maintaining the forest ecology. Therefore, this study was planned to know the duration 
of flowering and fruiting and environmental factors affecting them.

\section{MATERIALS AND METHODS}

\section{Study Sites}

Sampling was conducted in three forest reserves in the northern region of Peninsular Malaysia (Figure 2), namely: Segari Melintang Forest Reserve (SMFR; $04^{\circ}$ 19' 34” N, 100 34' 57' E) in Perak, Teluk Bahang Forest Reserve (TBFR; 05 26' 34' $\mathrm{N}, 100^{\circ} 13$ ' 14" E), and Bukit Mertajam Forest Eco-Park (BMFEP; 05 ${ }^{\circ} 21^{\prime} 57^{\prime}$ N, $100^{\circ} 28^{\prime} 58^{\prime \prime}$ E) in Pulau Pinang. SMFR was dominated by trees of the Dipterocarpaceae family with patches of alluvial freshwater

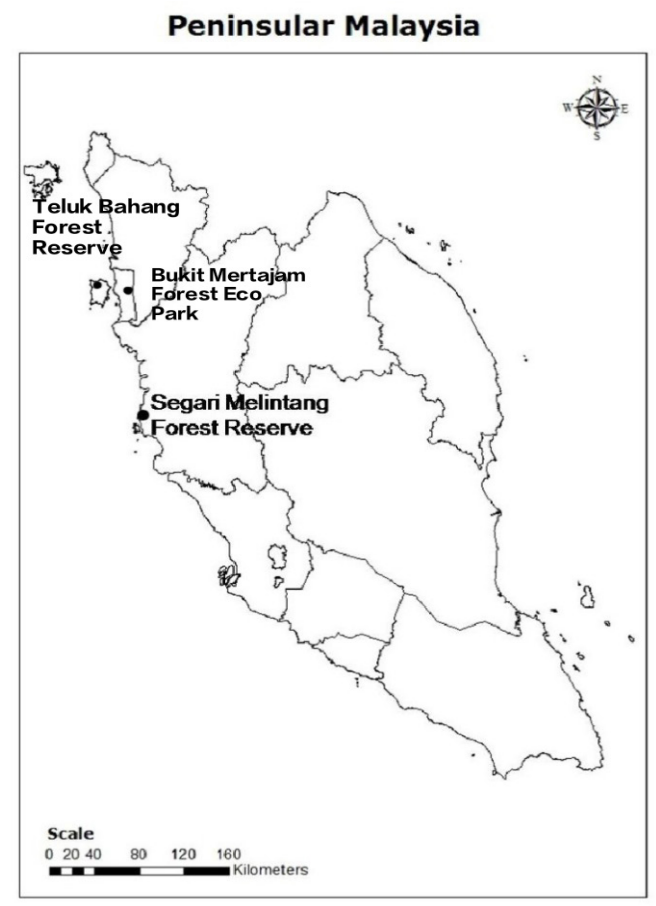

Figure 2. The map shows the location of the three study sites in Peninsular Malaysia swamp along the forest edge. The reserve comprises 408 hectares (ha) Virgin Jungle Reserve (VJR) that was strictly protected (Ruppert et al., 2016). TBFR is a lowland and hilly Dipterocarp Forest. One hundred and seventeenth hectares of TBFR were protected as VJR; meanwhile, BMFEP comprises a hilly dipterocarp forest covering 37 ha. This study started in March 2017 and was conducted for a year.

\section{Study Species}

Calamus castaneus is a dioecious, clustering acaulescent palm with no climbing organ (i.e., cirrus and/or flagella). Its leaves can grow up to $4 \mathrm{~m}$ long with a petiole length of $1.5 \mathrm{~m}$. One of the striking characteristics of C. castaneus is its grey spines with yellowish based and the presence of glaucous or dull dirty grey indumentose under the leaves. Female inflorescences have fewer branching than male inflorescences, with 15 rather stiff packed rachillas enclosed with compact bracts in fruit extending. Fruit is a scaly and rich chestnut brown coloured, $25 \mathrm{~mm}$ long and $18 \mathrm{~mm}$ wide when ripe (Dransfield, 1979). This species grew throughout Peninsular Malaysia except for Perlis (Dransfield, 1979) and was categorised as Not Evaluated (NE) under Malaysia Plant Red List.

\section{Population Structure and Sex Determination}

Five study plots (each $10 \mathrm{~m}$ x $10 \mathrm{~m}$, the distance between each plot is at least $50 \mathrm{~m}$ apart from each other) were established for a long-term rattan survey in the three sites. 
The cluster of rattan within the sampling plots was randomly distributed. Since $C$. castaneus is a common palm, the plants can be easily found alongside a small stream. Identification of the studied species was given by Dransfield (1979). The plants within the study plot were marked with numbered plastic tags. Only the plant that had borne inflorescences or infructescences were chosen. The distance between plots was made sure less than $50 \mathrm{~m}$ from each other to ensure that sampling for whole the population could be finished in a day. At each location, the population is comprised of 53 plants (28 males, 25 females). Observations of flowering determined the sex of each plant and fruiting from previous seasons noted that only female plants would bore infructescences. A complete sample of $C$. castaneus was collected from the field and deposited at the USM Herbarium with the catalogued number of USM Herbarium 11783.

\section{Monitoring Flowering and Fruiting}

The number of inflorescences was selected in each plot, and the number of female and male flowers in each inflorescence was recorded. Each individual's number of flowers produced was estimated by comparing the number of inflorescences produced by each flowering individual and the mean number of flowers per male and female inflorescences (Kidyoo \& McKey, 2012). On the other hand, the fruits per rachilla in infructescence were recorded. Through some modification from Kidyoo and McKey (2012), the number of fruits borne by each infructescence was estimated by the number of fruits per rachilla. The fruit width and length were measured each month using a ruler. Several fruits were taken back as a sample for a cross-section to observe the growth stages inside the fruit.

\section{Pollinators and Seed Dispersers}

Insect pollinators that regularly visited flowers of both sexes were observed and recorded. The visitation behaviour of insect visitors such as pollen collection, nectar collection, and contact with anthers of staminate flowers or stigma of pistillate flowers were recorded (Kidyoo \& McKey, 2012). The pollinators were captured by net using the caught-and-release method. Photographs were taken to identify the species. In addition, possible seed dispersers within the plot were examined by the track they had left, such as footprints or leftover fruits and seeds.

\section{Microclimate Sampling and Soil Properties Analysis}

Microclimate readings (i.e., light intensity, relative humidity, air temperature, soil temperature, percentage of gap opening, and level of disturbance) were noted between 10 a.m. until 12 p.m. every month (Hardwick et al., 2015). Light intensity was measured using a portable luxmeter (Model HI 97500 portable lux meter, Hanna Instruments, USA). In contrast, air temperature and relative humidity were measured using a portable thermo-hygrometer (Model HI 9564 portable, water-resistant thermohygrometers, Hanna Instruments, USA). 
The readings were taken 1.5 metres above ground within the plot near the cluster of $C$. castaneus. Soil temperature was measured using a soil thermometer by shoving the probe about $10 \mathrm{~cm}$ deep in the soil. Soil samples were collected near the cluster of studied species within the plot and brought back to the laboratory to analyse soil bulk density, soil $\mathrm{pH}$, soil moisture content, and soil texture analysis. Three soil samples were collected in each site's plot and were secured in a zip-lock plastic bag. Soil $\mathrm{pH}$ was determined with a soil $\mathrm{pH}$ meter using the 1:5 ratio of soil and water, respectively. Soil texture was determined with the mechanical method to find out the sand, silt, and clay. The determination of soil texture as in percentage of sand, silt and clay were referred to as United States Department of Agriculture (USDA) textural triangle (Brady $\&$ Weil, 2014).

\section{Canopy Gap Opening}

The percentage of canopy gap opening status (Table 1) and disturbance index (DI) (Table 2) were referred to by Mansor (2001).

Table 1

Percentage range and canopy gap opening status

\begin{tabular}{cc}
\hline Percentage range $(\%)$ & Gap opening status \\
\hline $0-25$ & Closed area \\
$26-40$ & Partly closed area \\
$41-60$ & Slightly opened area \\
$61-80$ & Partly opened area \\
$81-100$ & Highly opened area \\
\hline
\end{tabular}

\section{Disturbance Index}

Level of disturbance considering certain factors such as socioeconomic, ecology, and infrastructure were modified from
Mansor (2001) by Rozali (2014) using DI. The index was scaled from 1 to 5 , with one represented as the lowest disturbed and five as the highest disturbed (Table 2).

Table 2

Characterisation for disturbance criteria

\begin{tabular}{lr}
\hline Feature & Disturbance scale \\
\hline & Trails $\left(\mathrm{g}_{1}\right)$ \\
Infrastructure: & 1 \\
Unexplored forest overgrown by big trees & 2 \\
Unexplored forest and filled with bushes & \\
\hline
\end{tabular}


Table 2 (Continue)

\begin{tabular}{|c|c|}
\hline Feature & Disturbance scale \\
\hline & Trails $\left(\mathrm{g}_{1}\right)$ \\
\hline \multicolumn{2}{|l|}{ Infrastructure: } \\
\hline $\begin{array}{l}\text { Explored forest with small trails }<50 \mathrm{~cm} \text { width (rarely used by } \\
\text { visitors) }\end{array}$ & 3 \\
\hline $\begin{array}{l}\text { Explored forest with bigger trails }>50 \mathrm{~cm} \text { width (always used by } \\
\text { visitors) }\end{array}$ & 4 \\
\hline \multirow[t]{2}{*}{ Paved roads } & 5 \\
\hline & Visitors per day $\left(\mathrm{g}_{2}\right)$ \\
\hline
\end{tabular}

Socioeconomics:

$1-15$ visitors

16-25 visitors

26-35 visitors

36-45 visitors

$>45$ visitors

Ecology:

Virgin forest

Secondary forest

Reserve forest

Agriculture

Clearing's forest

Big streams or waterfalls

Watercourse

Recreational ponds

Damp

Dried area, no watercourse in the forest

$0-25 \%$

$26-40 \%$

$41-60 \%$

$61-80 \%$

4

$81-100 \%$

5 
The percentage of DI was calculated with the following formula:

$$
\mathrm{DI}=\mathrm{g}_{1}+\mathrm{g}_{2}+\mathrm{g}_{3}+\mathrm{g}_{4}+\mathrm{g}_{5}
$$

where:

$\mathrm{DI}=$ Disturbance index

$\mathrm{g}_{1}=$ Trails

$\mathrm{g}_{2}=$ Number of visitors

$\mathrm{g}_{3}=$ Land use $\mathrm{g}_{4}=$ Water supply

$\mathrm{g}_{5}=$ Gap forest cover

Percentage of disturbance $=\left[\left(g_{1}+g_{2}+g_{3}+\right.\right.$ $\left.\left.\mathrm{g}_{4}+\mathrm{g}_{5}\right) /(25)\right] \times 100$

The percentage of disturbance index (range) based on total disturbance index recorded from each plot, given in Table 3.

Table 3

Percentage range and disturbance status

\begin{tabular}{cc}
\hline Percentage range (\%) & Disturbance status \\
\hline $0-25$ & Low disturbed area \\
$25-50$ & Moderately low disturbed area \\
$50-75$ & Moderately high disturbed area \\
$75-100$ & Highly disturbed area \\
\hline
\end{tabular}

\section{Data Analysis}

The flowering and fruiting parameters of C. castaneus at all sites were recorded, and the duration of these was plotted in the graph. Microclimate data and soil properties analysis of each site were compiled and analysed using one-way analysis of variance (ANOVA) with post-hoc Tukey's test. The influence of microclimate and soil properties on the flowering and fruiting of C. castaneus were noted using canonical correspondence analysis (CCA) of CANOCO version 4.5 (Ter Braak, 1988).

\section{RESULTS AND DISCUSSION}

\section{Population Structure and Sex} Determination

Observations have been made on 53 studied plants (28 males, 25 females) in all sites for a year. All mature plants within the plots were observed monthly. From Table 4, SMFR denoted the highest number of males (16 individuals) and females (16 individuals), making it the highest number (32 individuals) of C. castaneus individual palm among all sites. Based on a year sampling, there was no existence of female plants in TBFR plots. A site survey during late 2016 on TBFR shows a limited number of female plants (personal observation). However, plots were not established in the presence of female plants due to safety precautions. Hence, a comparing the flowering duration of female plants can only be carried out between SMFR and BMFEP. It also applies to the duration of fruiting as only female plants would bear fruits. 
Nur Diana Mohd Rusdi, Asyraf Mansor, Shahrul Anuar Mohd Sah, Rahmad Zakaria and Nik Fadzly Nik Rosely

Table 4

Abundance of Calamus castaneus individuals by sexes in all investigated forests

\begin{tabular}{cccc}
\hline Sexes & $\begin{array}{c}\text { Teluk Bahang Forest } \\
\text { Reserve }\end{array}$ & $\begin{array}{c}\text { Segari Melintang } \\
\text { Forest Reserve }\end{array}$ & $\begin{array}{c}\text { Bukit Mertajam } \\
\text { Forest Eco Park }\end{array}$ \\
\hline Male & 6 & 16 & 6 \\
Female & - & 16 & 9 \\
Total & 6 & 32 & 15 \\
\hline
\end{tabular}

\section{Duration of Anthesis in Each Site}

The flowering structure of male and female inflorescences can be seen clearly as in Figures 3 and 4. Generally, male inflorescences bloomed for a more extended period and were also more highly branched, laxer, and sinuose than female inflorescences.

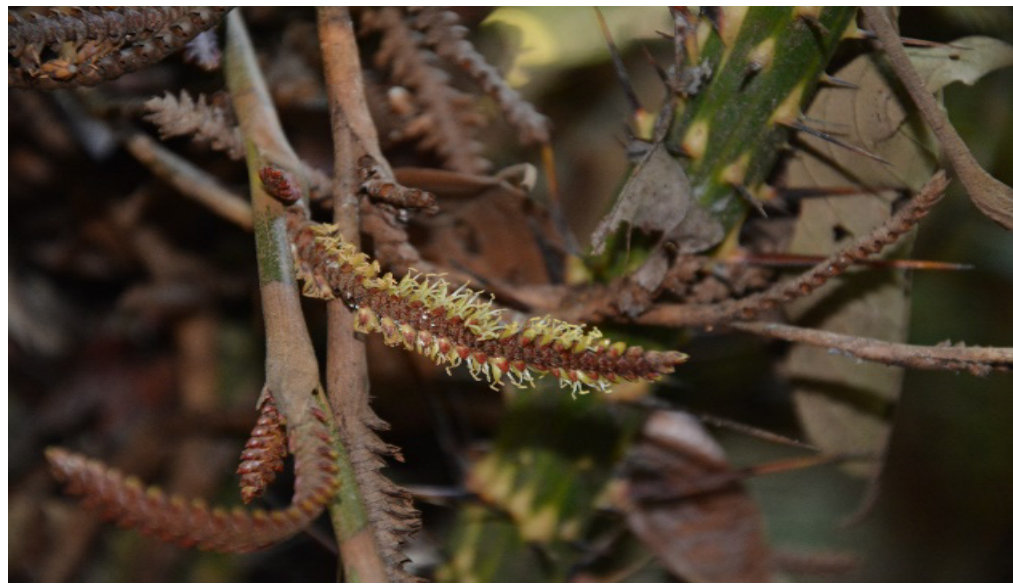

Figure 3. Male inflorescences were highly branched

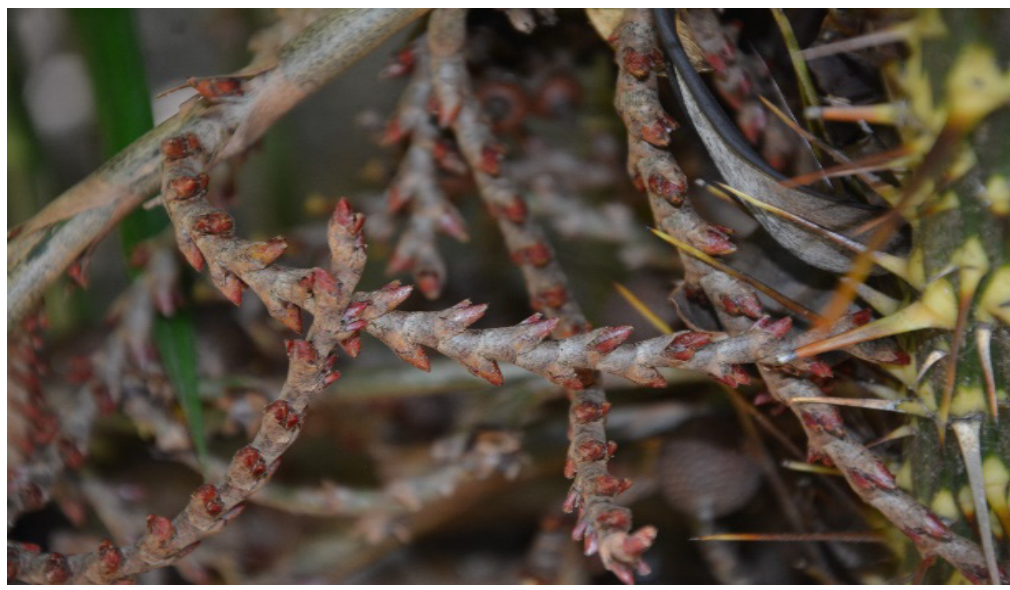

Figure 4. Female inflorescences with stiff crowded rachillae 
There were six individuals of male from one month to the longest four months. plants recorded in the TBFR site (Figure 5). At the end of the anthesis, the flower shed Among the six plants, only two individuals and both types of plants stopped producing displayed blooming throughout the year. flowers from October 2017 until the end of The blooming was very short, ranging the sampling period.

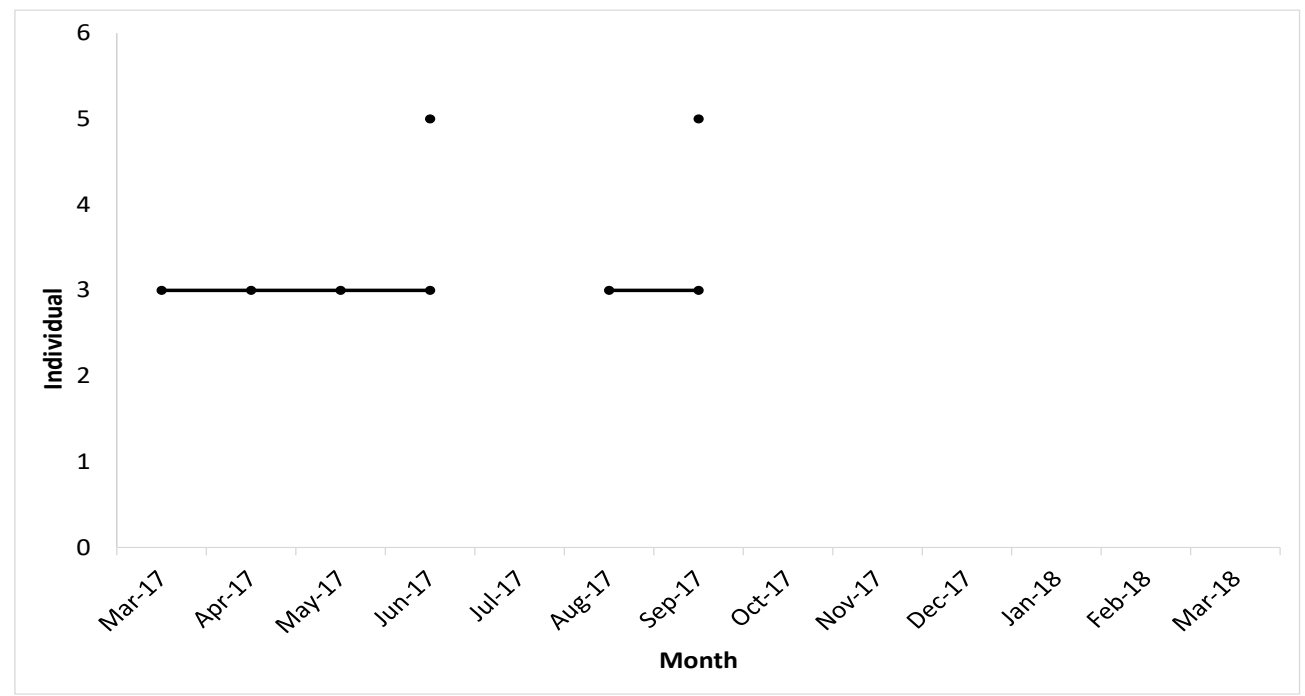

Figure 5. Duration of anthesis in Calamus castaneus male inflorescences in Teluk Bahang Forest Reserve

Plants of both sexes are flowered throughout the year. Based on Figure 6, the pattern of duration between male and female inflorescences was different. Male plants produced larger inflorescences with a greater degree of branching. Thus, male plants produced a more significant number of flowers compared with female plants (Kidyoo \& McKey, 2012). Almost all male inflorescences in SMFR flowered throughout the sampling period. Flowering time in male inflorescences occurred continuously. The largest gap for an individual not producing any flowers was six months $(\mathrm{n}=15)$, and the smallest gap was a month $(\mathrm{n}=6,9,11,12$, 13, and 14). Meanwhile, only one individual of female inflorescences bloomed for a year $(n=22)$. The shortest flowering time was in December 2017, when the female individual bloomed only for a month $(n=24)$.

Unlike SMFR, the flowering time of male and female inflorescences in BMFEP (Figure 7) were comparatively shorter. The longest blooming of male inflorescences was six months $(n=4)$ which started in May 2017 and ended in October 2017. Based on observation, two (2) individuals $(n=3$ and $\mathrm{n}=7$ ) do not produce any inflorescences at all. Most female inflorescences bloomed about two to three months on this site most of them producing flowers in August 2017. However, after September 2017, all- 
female inflorescences in BMFEP stopped producing a flower. All forest reserves and national parks in Pulau Pinang, including TBFR and BMFEP, were closed for visitors from November 2017 until January 2018 due to landslides and tree fall caused by the

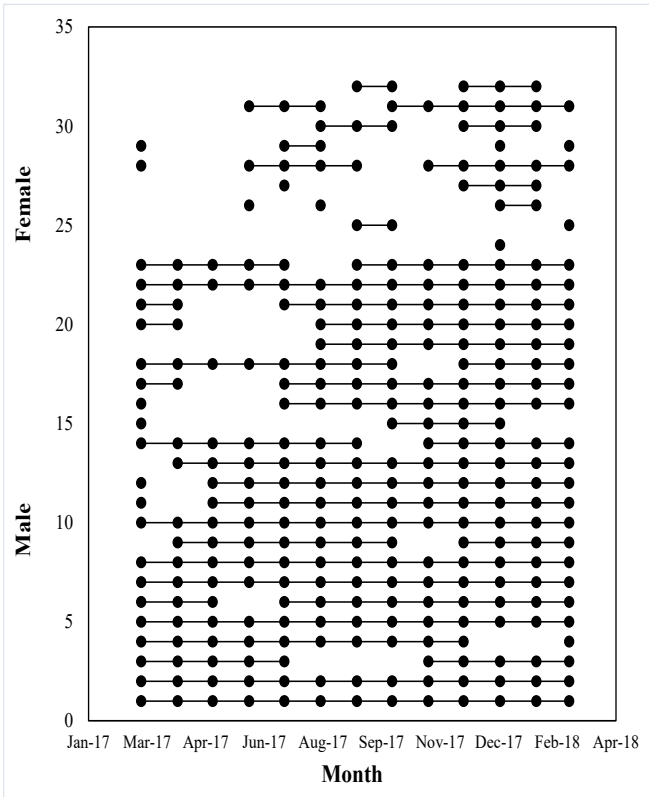

Figure 6. Duration of anthesis in Calamus castaneus male $(\mathrm{n}=1-16)$ and female $(\mathrm{n}=17-32)$ inflorescences in Segari Melintang Forest Reserve

\section{Duration of Fruiting}

Ripe fruit can grow to $25 \mathrm{~mm}$ long and 18 $\mathrm{mm}$ wide. The pronounced beak and rich chestnut colour can be seen as in Figure 8 . monsoon. Natural disasters and disturbances have had a destructive impact on the flowering of male inflorescences since there were no signs of blooming in TBFR and BMFEP during the period.

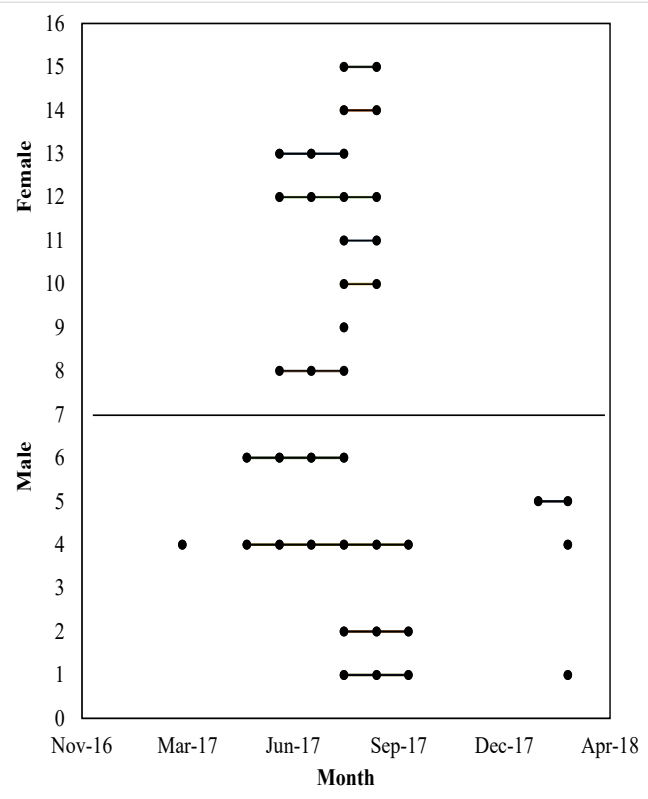

Figure 7. Duration of anthesis in Calamus castaneus male $(n=1-6)$ and female $(n=7-15)$ inflorescences in Bukit Mertajam Forest Eco Park

In this study, the duration of fruiting can only be compared in SMFR (16 individuals) and BMFEP (nine individuals) due to the absence of female plants of $C$. castaneus

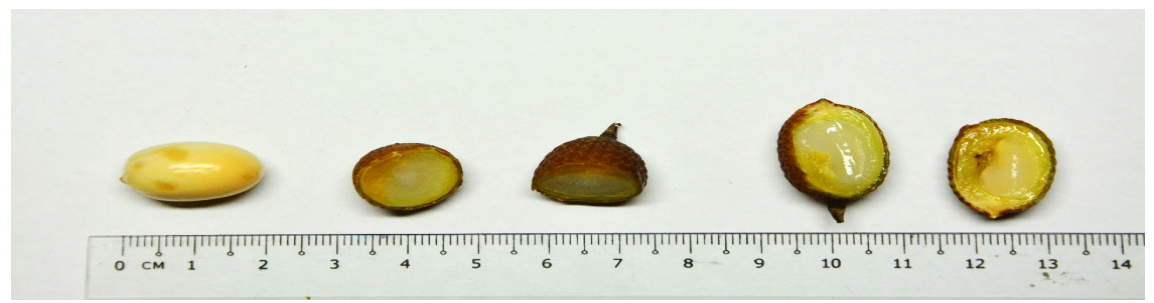

Figure 8. Cross-section of Calamus castaneus fruit 
inside the plot established in TBFR. Based on Figure 9, there were no female plants monitored to fruit throughout the year in BMFEP, whereas five individuals were observed to produce fruits throughout the year $(n=12,13,14,15,16)$ in SMFR. From observation, it took about 3 to 4 months for the fruits to reach their maturation. Nevertheless, not all fruits from one infructescence would reach maturity. Before they were ripe (personal observation), half of it was attacked by beetles, eaten by predators or infected by pyrenomycete fungus that filled the entire fruit. As a result, the scales appear to be embedded in black powder (Dransfield, 1979).

One individual of $C$. castaneus would exhibit different fruiting stages (ripe, unripe, budding, and flowering) simultaneously (Ruppert et al., 2014). However, it was assumed that all the flowers had already developed into fruits, and the flowering cycle could be halted until all the fruit was shed. Choong and Wickneswari (2016) discussed that dioecy in rattan had limited its breeding and cultivation. Besides that, gender in Calamus species can only be identified after the first flowering. Dransfield (1974) reported that rattan seeds would need one to six months to germinate. Female plants only produce the fruits and progeny, and the reducing number of mature fruits per inflorescences would affect the distribution and ratio of sexes in any locality (Manokaran, 1985: Renuka \& Rugmini, 2007). Hence, due to the dioecious nature of nearly all rattan, cross-pollination must occur. It was uncommon to find solitary female individuals bearing well-developed fruits but male plants being nowhere to be found as fruits could not be formed without pollen from male plants (Dransfield, 1979; Manokaran, 1985).

From Figure 9, C. castaneus fruits longer in SMFR than BMFEP. The average duration of fruiting in BMFEP is three months, and the most extended period of fruiting could reach about six months. However, C. castaneus in SMFR displayed various fruiting duration from one month to continuously fruiting for one year. The average period of fruiting recorded was three to four months. In addition, one same individual could fruit a year thrice after the fruit had already been shed. Although the pattern was quite non-uniformed, a single C. castaneus individual in this site could fruit up to four times in a year. Hence, the continuous production of $C$. castaneus fruit has been a great food source for the animal inside the forest. If animals do not eat it, the fruit will rot and fall on the forest floor, making a chance to develop a new seedling.

\section{Relationship between Environmental Variables with the Duration of Flowering and Fruiting of Calamus castaneus}

This study collected the data on environmental variables (i.e., microclimate parameters and soil properties) twice a month for a year. One-way ANOVA with post-hoc Tukey's test at $p<0.05$ was used to analyse the significant difference between each site. The significant differences were displayed in superscripts $a, b$, and c, as in Table 5. In Table 5, relative humidity, soil 


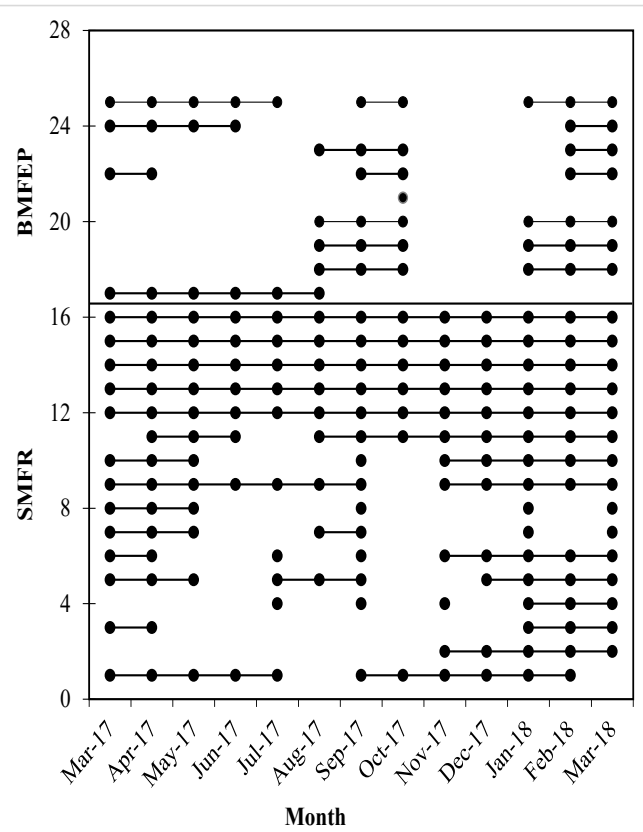

Figure 9. Duration of fruiting of Calamus castaneus in Segari Melintang Forest Reserve $(\mathrm{n}=1-16)$ and Bukit Mertajam Forest Eco Park $(\mathrm{n}=17-25)$ temperature, disturbance index level, soil $\mathrm{pH}$, and soil moisture content showed a significant difference between each site. Lara et al. (2017) added that different environmental variables, i.e., relative humidity and cloudiness, may influence the flowering pattern observed. However, the rest of the environmental variables shows no significant differences. Aminuddin (1985), Manokaran (1985), and Nainggolan (1985) stated that environmental parameters such as listed in Table 5 could affect rattan growth and survival in the forest. However, the interaction between rattan flora and soil type is still not clear.

Table 5

Environmental variables parameter (Mean \pm SE) measured from March 2017 until March 2018 summarised in table showed

\begin{tabular}{lccc}
\hline Parameter & TBFR & SMFR & BMFEP \\
\hline Relative humidity $(\%)$ & $83.70 \pm 1.34^{\mathrm{b}}$ & $71.59 \pm 2.21^{\mathrm{a}}$ & $81.14 \pm 2.18^{\mathrm{b}}$ \\
Air temperature $\left({ }^{\circ} \mathrm{C}\right)$ & $25.0 \pm 2.14^{\mathrm{a}}$ & $28.50 \pm 1.01^{\mathrm{a}}$ & $25.35 \pm 0.40^{\mathrm{a}}$ \\
Light intensity $(\mathrm{kLux})$ & $1.00 \pm 0.18^{\mathrm{a}}$ & $1.11 \pm 0.18^{\mathrm{a}}$ & $1.10 \pm 0.18^{\mathrm{a}}$ \\
Soil temperature $\left({ }^{\circ} \mathrm{C}\right)$ & $26.15 \pm 0.10^{\mathrm{b}}$ & $26.81 \pm 0.15^{\mathrm{c}}$ & $24.28 \pm 0.14^{\mathrm{a}}$ \\
Canopy gap opening $(\%)$ & $25.5 \pm 4.77^{\mathrm{a}}$ & $46.7 \pm 8.47^{\mathrm{a}}$ & $36.4 \pm 5.41^{\mathrm{a}}$ \\
Disturbance index $(\%)$ & $37.6 \pm 0.98^{\mathrm{b}}$ & $30.8 \pm 2.15^{\mathrm{a}}$ & $60.8 \pm 1.5^{\mathrm{c}}$ \\
Soil pH & $5.74 \pm 0.15^{\mathrm{b}}$ & $6.09 \pm 0.33^{\mathrm{b}}$ & $4.82 \pm 0.05^{\mathrm{a}}$ \\
Soil moisture content $(\%)$ & $24.82 \pm 0.65^{\mathrm{a}}$ & $32.26 \pm 3.30^{\mathrm{a}}$ & $45.26 \pm 3.70^{\mathrm{b}}$ \\
Soil bulk density $\left.(\mathrm{gcm})^{-3}\right)$ & $0.97 \pm 0.12^{\mathrm{a}}$ & $0.91 \pm 0.14^{\mathrm{a}}$ & $0.76 \pm 0.09^{\mathrm{a}}$ \\
Soil texture analysis & Sand & Sand & Loamy sand \\
\hline
\end{tabular}

Note. Superscript a, b, and c indicates the significant difference at $p<0.05$ by post-hoc Tukey's test in each parameter between sites. TBFR $=$ Teluk Bahang Forest Reserve; SMFR = Segari Melintang Forest Reserve; $\mathrm{BMFEP}=$ Bukit Mertajam Forest Eco-Park 
The CCA of plant production and environmental variables, as summarised in Table 6, shows that the eigenvalue was less than 0.5 , which indicate that species-environment relation was low. The cumulative variance explained by the first three-axis of the species-environment relationship in the CCA of TBFR, SMFR, and BMFEP were all 0\% (Tables 6, 7, and 8). The CCA ordination plot was displayed as in Figures 10, 11, and 12. The direction and length of the arrow that extends from the centre of the ordination diagram displayed the strength between plant production and environmental variables.

Table 6

Summary of the canonical correspondence analysis (CCA) of the Calamus castaneus plant production and environmental data in Teluk Bahang Forest Reserve

\begin{tabular}{|c|c|c|c|c|c|}
\hline Axes & 1 & 2 & 3 & 4 & $\begin{array}{c}\text { Total } \\
\text { inertia }\end{array}$ \\
\hline Eigenvalues & 0.002 & 0.058 & 0 & 0 & 0.061 \\
\hline Species-environment correlations & 0.201 & 0 & 0 & 0 & \\
\hline \multicolumn{6}{|l|}{ Cumulative percentage variance } \\
\hline of species data & 4.1 & 100 & 0 & 0 & \\
\hline of species-environment relation & 100 & 0 & 0 & 0 & \\
\hline Sum of all eigenvalues & & & & & 0.061 \\
\hline Sum of all canonical eigenvalues & & & & & 0.002 \\
\hline
\end{tabular}

Figure 10 displays that all ten (10) environmental variables listed in this study do not affect flower production in TBFR. The arrow of environmental variables lies on the horizontal axis, which means the was no relationship of microclimate parameters and soil properties on the generation of $C$. castaneus flower in TBFR.

SMFR has displayed the longest and most frequent flowering duration over the year. Hence, Figure 11 represents the environmental variables that influence the duration of its flowering. Based on Eigenvalues, high soil $\mathrm{pH}$ value, and increased soil bulk density will reduce the duration of flowering and fruiting of $C$. castaneus. Although some rattan species need high soil $\mathrm{pH}$ to grow, others demand low soil $\mathrm{pH}$. However, too acidic soil will affect rattan development and eventually will retard the plant. In addition, soil $\mathrm{pH}$ will affect mineral nutrient availability on rattan growth as some nutrients become inaccessible at certain $\mathrm{pH}$ levels (Lilly, 2010). Moreover, compacted soil will inhibit the growth of roots, reduce the movement of gaseous exchange in the root zone and may also decrease water diffusion (Brady \& Weil, 2014; Lilly, 2010). 


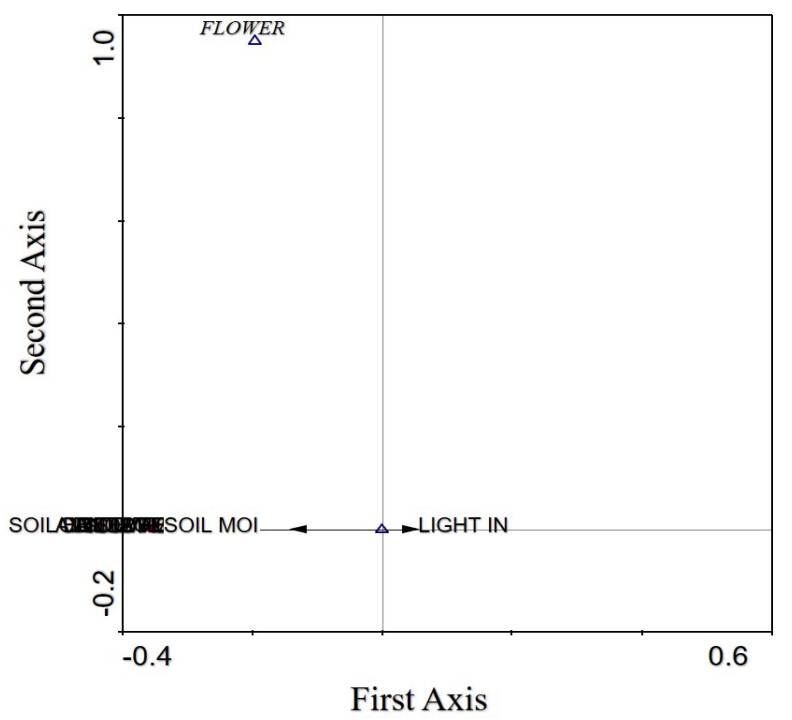

Figure 10. Ordination plot of canonical correspondence analysis (CCA) between environmental variables (arrows) with flower (triangles) in Teluk Bahang Forest Reserve

Note. SBD = Soil bulk density; DI = Disturbance index; $\mathrm{RH}=$ Relative humidity; SOIL TEMP $=$ Soil temperature; AIR TEMP = Air temperature; $\mathrm{PH}=$ Soil $\mathrm{pH}$; SOIL MOI = Soil moisture content; LIGHT IN = Light intensity; GAP = Percentage of gap opening

Table 7

Summary of the canonical correspondence analysis (CCA) of the Calamus castaneus plant production and environmental data in Segari Melintang Forest Reserve

\begin{tabular}{|c|c|c|c|c|c|}
\hline Axes & 1 & 2 & 3 & 4 & $\begin{array}{c}\text { Total } \\
\text { inertia }\end{array}$ \\
\hline Eigenvalues & 0.012 & 0.002 & 0.085 & 0.038 & 0.137 \\
\hline Species-environment correlations & 0.35 & 0.24 & 0 & 0 & \\
\hline \multicolumn{6}{|l|}{ Cumulative percentage variance } \\
\hline of species data & 8.6 & 10.3 & 72.1 & 100 & \\
\hline of species-environment relation & 83.1 & 100 & 0 & 0 & \\
\hline Sum of all eigenvalues & & & & & 0.137 \\
\hline Sum of all canonical eigenvalues & & & & & 0.014 \\
\hline
\end{tabular}




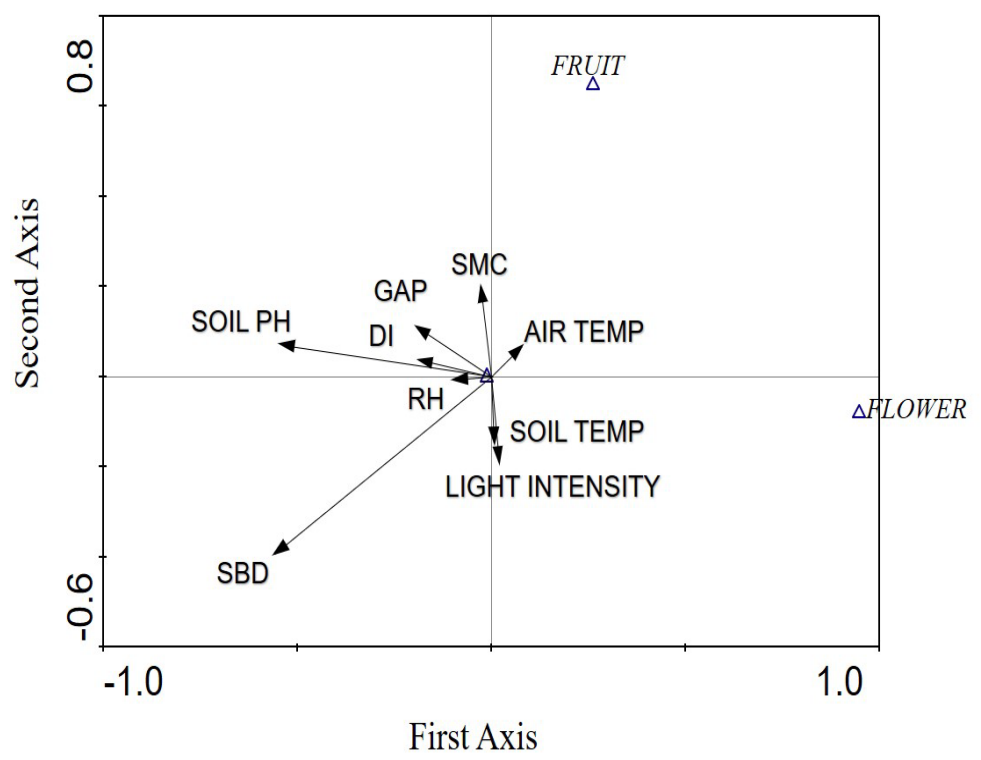

Figure 11. Ordination plot of canonical correspondence analysis (CCA) between environmental variables (arrows) with flower and fruit (triangles) in Segari Melintang Forest Reserve

Note. SBD = Soil bulk density; DI = Disturbance index; RH = Relative humidity; SOIL TEMP $=$ Soil temperature; AIR TEMP = Air temperature; $\mathrm{SMC}=$ Soil moisture content; GAP = Percentage of gap opening

\section{Table 8}

Summary of the canonical correspondence analysis (CCA) of the Calamus castaneus plant production and environmental data in Bukit Mertajam Forest Eco-Park

\begin{tabular}{lccccc}
\hline Axes & 1 & 2 & 3 & 4 & $\begin{array}{c}\text { Total } \\
\text { inertia }\end{array}$ \\
\hline $\begin{array}{l}\text { Eigenvalues } \\
\text { Species-environment correlations }\end{array}$ & 0.02 & 0.00 & 0.13 & 0.11 & 0.27 \\
$\begin{array}{l}\text { Cumulative percentage variance } \\
\quad 0.38\end{array}$ & 0.17 & 0.00 & 0.00 & \\
$\quad \begin{array}{l}\text { of species data } \\
\text { of species-environment relation }\end{array}$ & 7.8 & 9.2 & 58.4 & 100 & \\
Sum of all eigenvalues & 84.9 & 100 & 0 & 0 & \\
Sum of all canonical eigenvalues & & & & & 0.269 \\
\hline
\end{tabular}


The CCA graph in Figure 12 and eigenvalue in Table 8 show high relative humidity, percentage of gap opening, soil temperature, disturbance index level, soil $\mathrm{pH}$, and air temperature would give positive feedback on flowers and fruits production. Manokaran (1989) stated that a period of high rainfall after dry seasons and high temperatures would trigger flowering in rattan. An increase in soil moisture content would decrease fruiting but increase flowering. In the meantime, the low light intensity would stimulate flowering and promotes fruiting. Some rattan species were able to grow under the lower light condition with well-established canopies and soil with good moisture (Powling, 2004).

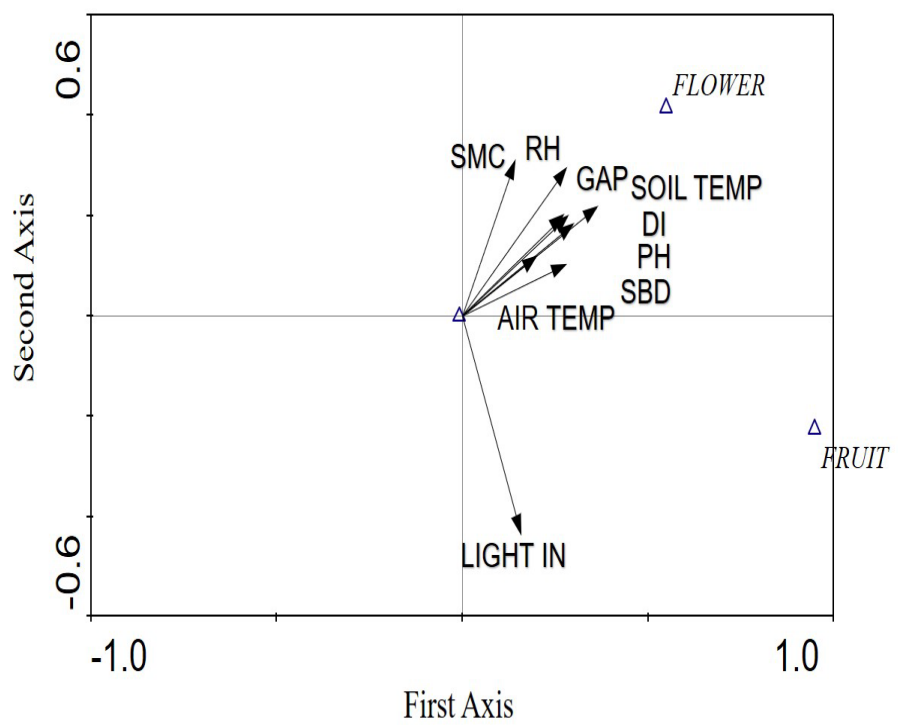

Figure 12. Ordination plot of canonical correspondence analysis (CCA) between environmental variables (arrows) with flower and fruit (triangles) in Bukit Mertajam Forest Eco-Park

Note. SMC $=$ Soil moisture content; $\mathrm{RH}=$ Relative humidity; GAP = Percentage of gap opening; SOIL TEMP = Soil temperature DI = Disturbance index PH = Soil $\mathrm{pH} ; \mathrm{SBD}=$ Soil bulk density; AIR TEMP = Air temperature; LIGHT IN = Light intensity 
New Shoot from Female Inflorescences of Calamus castaneus

During the sampling period in SMFR, we record a female individual that produces a new vegetative shoot from the apex of the inflorescences as in Figure 13 (GPS: N 04 19' 34.7"' E $100^{\circ} 34$ ' 57.9"). The $C$. castaneus individual palm was found near a small stream. This individual spotted a growing shoot in early October 2017 and slowly dried at the end of November 2017. It was then eventually turning brown completely and died in March 2018. Throughout the observation period, the shoot does not produce any roots. Besides that, fresh flowers and edible fruit were present on the same plants. The same event occurred in SMFR as Ruppert et al. (2012) recorded but on male inflorescence. Until today, we still do not know whether this phenomenon is another form of sexual reproduction or just another mutant.

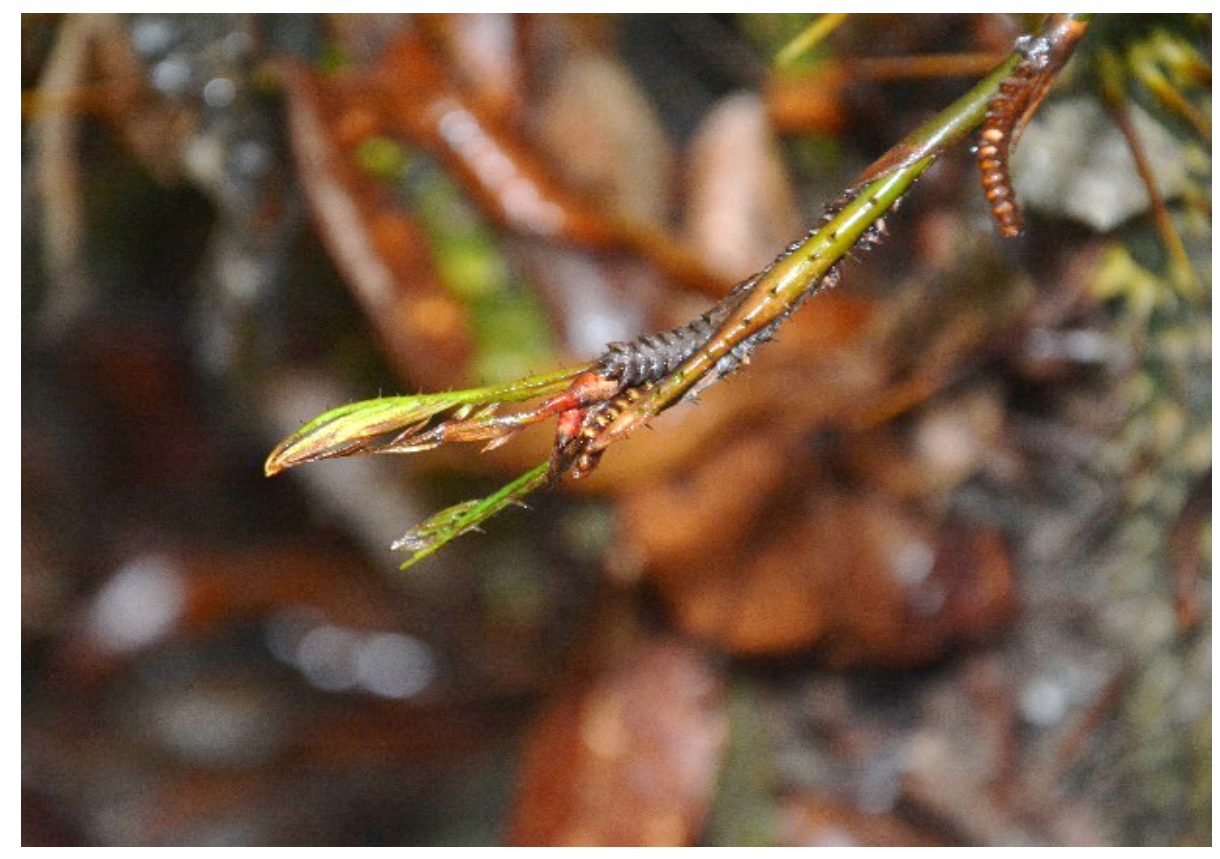

Figure 13. New vegetative shoot from female inflorescence apex

\section{CONCLUSION}

Overall, female inflorescences bloomed shorter than males. On average, female inflorescences would bloom for two to three months while male inflorescences for six months. However, the fruit of Calamus casteneus mature in three to four months. It has been observed that flowering and fruiting are highly regulated by microclimate and locality but did not significantly affect by a very specific environmental factor. 


\section{ACKNOWLEDGEMENTS}

USM RU Research Grant supported this project (Research grant number 1001/ PBIOLOGI/8011031). The authors would like to thank Peninsular Malaysia Forestry Department for issuing the respective permits.

\section{REFERENCES}

Ali, A. R. M., \& Barizan, R. S. R. (2001). Important rattan species of Malaysia. http://www.fao.org/3/ x9923e/x9923e07.htm

Aminuddin, M. (1985). Performances of some rattan species in growth trials in Peninsular Malaysia. https://www.inbar.int/wp-content/ uploads $/ 2020 / 05 / 1493102176$.pdf $\#$ page $=43$

Brady, N. C., \& Weil, R. R. (2014). The nature and properties of soils (14th ed.). Pearson Education Limited.

Choong, C. Y., \& Wickneswari, R. (2016). Sexing in rattans. Malaysian Applied Biology, 45(2), 1-10.

Dransfield, J. (1974). A short guide to rattan. Regional Centre for Tropical Biology.

Dransfield, J. (1979). A manual of the rattans of the Malay Peninsula. Forest Department, Ministry of Primary Industries Malaysia.

Dransfield, J. (2001). Taxonomy, biology and ecology of rattan. Unasylva, 52(205), 11-13.

Hardwick, S. R., Toumi, R., Pfeifer, M., Turner, E. C., Nilus, R., \& Ewers, R. M. (2015). The relationship between leaf area index and microclimate in tropical forest and oil palm plantation: Forest disturbance drives changes in microclimate. Agricultural and Forest Meteorology, 201, 187-195. https://doi. org/10.1016/j.agrformet.2014.11.010

Kidyoo, A. M., \& McKey, D. (2012). Flowering phenology and mimicry of the rattan Calamus castaneus (Arecaceae) in southern Thailand.
Botany, 90(9), 856-865. https://doi.org/10.1139/ b2012-058

Lara, C. E., Díez, M. C., Restrepo, Z., Núñez, L. A., $\&$ Moreno, F. (2017). Flowering phenology and flower visitors of the Macana palm Wettinia kalbreyeri (Arecaceae) in an Andean montane forest. Revista Mexicana de Biodiversidad, 88(1), 106-112. https://doi.org/10.1016/j. rmb.2017.01.001

Lilly, S. J. (2010). Arborists' certification guide. Internal Society of Arboriculture.

Manokaran, N. (1985). Biological and ecological considerations pertinent to the silviculture of rattans. In K. M. Wong \& N. Manokaran (Eds.), Proceedings of Rattan Seminar (pp. 95-105). The Rattan Information Centre.

Manokaran, N. (1989). Flowering and fruiting patterns of Calamus caesius Bl. In A. N. Rao \& I. Vongkaluang (Eds.), Recent Research on Rattan: Proceedings of the International Rattan Seminar (pp. 122-129). Kasetsart University.

Mansor, A. (2001). Kajian kepelbagaian dan ekologi rumpai di kawasan hutan paya Semenanjung Malaysia [Study of the diversity and ecology of weeds in the swamp forest area of Peninsular Malaysia] [Unpublished Doctoral thesis]. Universiti Sains Malaysia.

Nainggolan, P. H. J. (1985). Preliminary observations on the effect of different canopy and soil moisture conditions on the growth of Calamus Manan (Manau). In K. M. Wong \& N. Manokaran (Eds.), Proceedings of Rattan Seminar (pp. 72-76). The Rattan Information Centre.

Powling, A. (2004). Rattans : Taxonomy and ecology (LIPI report 2004). https://www.opwall.com/ uploads/2017/11/Opwall-Indonesia-ButonRattan-Report-2004.pdf

Renuka, C., \& Rugmini, P. (2007). Development of conservation strategies for selected, endangered rattan species of the Western Ghats. http:/docs. kfri.res.in/KFRI-RR/KFRI-RR295.pdf 
Rozali, W. N. F. Z. W. (2014). Composition of rattan communities (Arecaceae, subfamily Calamoideae) in forest reserves of Penang [Unpublished Master's thesis]. Universiti Sains Malaysia.

Ruppert, N., Mansor, A., \& Anuar Mohd Sah, S. (2012). New shoot from inflorescences in Calamus castaneus in Peninsular Malaysia. Palms, 56(1), 36-40.

Ruppert, N., Mansor, A., \& Anuar Mohd Sah, S. (2014). A key role of the Southern pig-tailed macaque Macaca nemestrina (Linnaeus) in seed dispersal of non-climbing rattans in Peninsular Malaysia. Asian Primates Journal, 4(2), 42-51.

Ruppert, N., Mansor, A., \& Anuar Mohd Sah, S. (2016). Rattan (Calamoideae) abundance and above-ground biomass at a primary rainforest of Peninsular Malaysia. Plant Ecology and Diversity, 9(1), 63-67. https://doi.org/10.1080/ 17550874.2015 .1081650
Ter Braak, C. J. F. (1988). CANOCO - A FORTRAN program for canonocal community ordination by (partial) (detrended) (canonical) correspondence analysis, pincipal components analysis and redundancy analysis (version 2.1). Agricultural Mathematics Group.

Wan Ariffin, W. T., Rene, K., Muralidharan, E. M., Sreekumar, V. B., Chowdhary, C., Sheng, L. R., Viet, T. L., Sunderland, T., Haider, R., Tekpetey, S., Olorunnisola, A. O., Achdiawan, R., \& Hourt, H. E. (2018). Rattan terminologies. International Bamboo and Rattan Organisation (INBAR).

Watanabe, N. M., \& Suzuki, E. (2008). Species diversity, abundance, and vertical size structure of rattans in Borneo and Java. Biodiversity and Conservation, 17(3), 523-538. https://doi. org/10.1007/s10531-007-9268-1 
